\title{
A novel inhibitor of hypoxia-inducible factor- $1 \alpha$ P3155 also modulates PI3K pathway and inhibits growth of prostate cancer cells
}

\author{
Sonal M Manohar ${ }^{1 \dagger}$, Amol A Padgaonkar ${ }^{1 \dagger}$, Archana Jalota-Badhwar ${ }^{1}$, Vinay Sonawane $^{1}$, Maggie J Rathos ${ }^{1}$,
} Sanjay Kumar ${ }^{2}$ and Kalpana S Joshi ${ }^{3^{*}}$

\begin{abstract}
Background: Hypoxia-inducible factor-1 (HIF-1) is a master regulator of the transcriptional response to hypoxia. It is essential for angiogenesis and is associated with tumor progression and overexpression of HIF-1 $\alpha$ has been demonstrated in many common human cancers. Therefore, HIF-1 $\alpha$ is one of the most compelling anticancer targets.

Methods: To identify HIF-1 $\alpha$ inhibitors, luciferase reporter gene assay under hypoxia and normoxia was used. Detailed studies such as western blotting, RT-PCR, immunofluorescence were carried out to elucidate its mechanism of action. Antiangiogenic activity of P3155 was demonstrated by migration assay and tube formation assay. Efficacy study of P3155 was performed on PC-3 xenograft model.

Results: P3155 showed specific HIF-1 $\alpha$ inhibition with $\mathrm{IC}_{50}$ of $1.4 \mu \mathrm{M}$ under hypoxia. It suppressed HIF-1 $\alpha$ expression as well as PI3K/Akt pathway and abrogated expression of HIF-1-inducible gene viz. vascular endothelial growth factor (VEGF). P3155 in combination with HIF-1 $\alpha$ siRNA showed significant synergistic effect. In addition, it demonstrated significant in vivo efficacy and antiangiogenic potential in prostate cancer cell lines.

Conclusion: We have identified a novel HIF-1 $\alpha$ inhibitor P3155 that also modulates PI3K/Akt pathway, which may contribute to its significant in vitro and in vivo antitumor activity.
\end{abstract}

Keywords: P3155, HIF-1 $\alpha$ ?a?, prostate cancer, PI3K

\section{Background}

Hypoxia is a common phenomenon in rapidly growing solid tumors, and an important microenvironmental factor that contributes to the development of more malignant phenotypes [1,2]. It triggers adaptive responses in solid tumors that include induction of angiogenesis and a switch to anaerobic metabolism [3]. Cells adapt to hypoxia by down-regulating oxygen- and energy-dependent processes, such as mRNA translation or protein synthesis [4] while simultaneously up-regulating specific genes that promote angiogenesis and stress survival.

\footnotetext{
* Correspondence: kalpana.joshi@piramal.com

† Contributed equally

${ }^{3}$ Target Identification Group, Piramal Life Sciences Limited, 1-Nirlon Complex, Goregaon, Mumbai-400 063, India

Full list of author information is available at the end of the article
}

HIF-1 is a heterodimeric protein and is composed of oxygen sensitive HIF- $1 \alpha$ and constitutively expressed HIF-1 $\beta$ /ARNT subunit. Under nonhypoxic conditions, HIF- $1 \alpha$ protein is rapidly and continuously degraded by ubiquitination and proteasomal degradation. Degradation of HIF- $1 \alpha$ is dependent on binding with von Hippel-Lindau and hydroxylation of Pro-564 via an enzymatic process that requires $\mathrm{O}_{2}$ and iron $[5,6]$. However, under hypoxic conditions, prolyl hydroxylases become inactivated, and thus, HIF- $1 \alpha$ is stabilized and HIF-1 activated.

In many human tumors, HIF-1 $\alpha$ has been found to be highly expressed due to hypoxia or when oncogenes or tumor suppressor genes are mutated. Immunohistochemical analyses show that HIF-1 $\alpha$ is present at higher levels in human tumors than in normal tissues [7]. Furthermore, a correlation between HIF-1 $\alpha$ overexpression and

\section{Biomed Central}


resistance to radiation therapy or chemotherapy leading to poor patient prognosis has been observed [8]. Moreover, tumor growth and angiogenesis in xenograft tumors also depends on HIF-1 activity and on the HIF- $1 \alpha$ expression [9]. Thus, HIF-1 $\alpha$ is viewed as an excellent target for the development of novel cancer therapeutics [10].

Recently we focused our efforts on the development of novel inhibitors of HIF- $1 \alpha$ We screened for small molecules to find inhibitors of HIF accumulation under hypoxic condition. In our quest for finding potential therapeutics, we used pyridylpyrimidine as a basic scaffold; various molecules were designed, synthesized and characterized. Out of these molecules, P3155 and P2630 were identified as potent and specific HIF-1 $\alpha$ inhibitors in the reporter gene-based assay [ref [11]- structure 7 and 4 a respectively]. Herein, we report the anticancer activity and mechanism of action of P3155.

\section{Methods}

\section{Cell culture}

Human prostate cancer cell lines PC-3 and DU145 were cultured in RPMI-1640 containing 10\% fetal bovine serum (FBS) (Hyclone, UT, USA), $2 \mathrm{mmol} / \mathrm{L}$ L-glutamine (Gibco, Grand Island, NY, USA), $100 \mathrm{U} / \mathrm{ml}$ penicillin and $100 \mathrm{mg} / \mathrm{ml}$ streptomycin (Gibco). Human umbilical vein endothelial cells (HUVECs) were obtained from Cascade Biologics (Oregon, USA) and were cultured in M-200 medium (Cascade Biologics) supplemented with low serum growth supplements (LSGS) (Cascade Biologics), penicillin-G $(100 \mathrm{U} / \mathrm{ml})$, streptomycin $(100 \mu \mathrm{g} / \mathrm{ml})$ and amphotericin B (50 ng/ml) (Gibco). The cell lines were maintained in a humidified incubator at $37^{\circ} \mathrm{C}$ and $5 \%$ $\mathrm{CO}_{2}$. Topotecan was purchased from Calbiochem. P3155 was synthesized at Piramal Life Sciences Ltd., Mumbai, India. Both the compounds were dissolved in dimethyl sulfoxide (DMSO) at a concentration of $10 \mathrm{mmol} / \mathrm{L}(10$ $\mathrm{mM}$ ) and stored at $-20^{\circ} \mathrm{C}$ until use; were diluted in culture medium RPMI-1640 immediately before use and was used within $4 \mathrm{~h}$. All reagents were purchased from Sigma Chemical (St Louis, MO, USA) unless otherwise mentioned.

\section{Luciferase Reporter assay}

U251-HRE and U251-pGL3 cell lines were procured from Dr. Giovanni's Lab and maintained as described by Rapisarda et al previously [12]. Luciferase reporter gene assay was carried out using both these cell lines as described previously in detail [12]. Data was analyzed to determine the $\mathrm{EC}_{50}$ concentration (concentration of compound that inhibited luciferase expression by $50 \%$ ).

\section{Western blot analysis}

PC-3 cells were used for western blot analysis as described earlier [13]. Compounds were added according to concentrations and desferoxamine (DFX) (hypoxia mimick) at a final concentration of $60 \mu \mathrm{mol} / \mathrm{L}$ was added to each of the plates except the control (no DFX) plate. The plates were then incubated in a humidified incubator $\left(5 \% \mathrm{CO}_{2}\right)$ for $8 \mathrm{~h}$ and then harvested. The antibodies used were anti-HIF-1 $\alpha$ monoclonal antibody (BD Biosciences, CA), anti-p-Akt473, anti-p-4E-BP1 antibody (Cell Signaling Technology) or anti- $\beta$-actin antibody (Sigma).

\section{Reverse transcription-PCR}

For RT-PCR analysis, total cellular RNA was isolated with TRI reagent (Sigma, USA). cDNA synthesis was carried out and PCR was performed on CDNA with $2 \times$ PCR master mix (Fermentas, USA) and the corresponding primers. The following primers were used-HIF-1 $\alpha$ Forward primer TATGACCTGCTTGGTGCTGA Reverse primer GGGAGAAAATCAAGTCGTGC annealing temperature of $60^{\circ} \mathrm{C}$ and cycle no. 32. Tubulin: Forward primer TCTGTTCGCTCAGGTCCTTTTGGCC Reverse primer CGTACCACATCCAGGACAGA annealing temperature of $55^{\circ} \mathrm{C}$ and cycle no. 30. VEGF Forward primer AACTTTCTGCTGTCTTGG Reverse primer TTTGGT CTGCATTCACAT annealing temperature $55^{\circ} \mathrm{C}$ cycle no. 35. An aliquot of each reaction mixture was analyzed by electrophoresis on a $1.5 \%$ agarose gel and the gel images were obtained using Quantity one software (Bio Rad, USA).

\section{Immunofluorescence}

Cells $\left(0.3 \times 10^{6}\right)$ were seeded onto poly-D-lysine coated glass coverslips and incubated overnight. Cells were untreated or exposed to $60 \mu \mathrm{mol} / \mathrm{L}$ DFX for $8 \mathrm{~h}$, in the absence or presence of different concentrations of P3155 and processed for immunofluorescence staining as described earlier [14]. The antibodies used were: mouse monoclonal anti-HIF- $1 \alpha$ antibody (BD Transduction Labs, CA, USA), rabbit polyclonal anti-VEGF antibody (Santa Cruz Biotechnology, CA, USA), FITCconjugated anti-mouse antibody, Cy3-conjugated antirabbit antibody (Chemicon International, USA). Images were captured using fluorescent microscope.

\section{SiRNA mediated RNA interference}

Cells were plated in 6 well plates in FBS-free and antibiotic-free media. The cells were transiently transfected with siRNA (HIF-1 $\alpha$-specific siRNA or non-specific siRNA, QIAGEN, USA) using Lipofectamine2000 Transfection Reagent (Invitrogen, Carlsbad, CA) and allowed to stabilize for $24 \mathrm{~h}$, before being used in experiments.

\section{Migration assay}

Cells were seeded at a density of $(0.5-2.0) \times 10^{6}$ per well in a sterile 6 well plate. The plates were incubated overnight in humidified $\mathrm{CO}_{2}$ incubator $\left(5 \% \mathrm{CO}_{2}\right)$ at $37^{\circ}$ 
$\mathrm{C}$ under ambient oxygen levels for the cells to form a confluent uniform monolayer on the complete surface of the well. The cell monolayer was scraped to create a "scratch" with a pipette tip and the first image of the scratches was acquired. Compounds were added at various concentrations and the plates were further incubated for $24 \mathrm{~h}$. After the incubation, the plate was placed under a phase contrast microscope, reference point was matched, the photographed regions of the first image were aligned and the second image was acquired.

\section{D Gel Endothelial Tube formation assay}

The BD Matrigel Matrix (BD Biosciences, USA) was thawed at $4{ }^{\circ} \mathrm{C}$ overnight on ice. HUVEC endothelial cells were cultured to $60-80 \%$ confluence. Endothelial cell suspensions were prepared by trypsinizing the monolayers and resuspending the cells in culture medium with $5-10 \%$ serum (used as an angiogenesis promoter). $0.5-1 \times 10^{6}$ cells per $180 \mu$ l were added (per well of 24 well plate) of thawed BD Matrigel Matrix. The cells were allowed to adhere for 2-3 h. Subsequently, the compounds were added at appropriate concentrations to the respective wells. Appropriate control (medium control) was employed. Following $24-48 \mathrm{~h}$ of incubation, the cells were observed under the microscope for tube formation and angiogenesis.

\section{In vivo studies}

The human prostate cancer cells (PC-3) were grown and harvested. Cells were resuspended in saline at 10 million cells/0.2 mL volume and placed on ice. Severe combined immunodeficient mice were injected in $0.2 \mathrm{~mL}$ volume s.c. on the right flank and observed daily for tumor appearance. When the tumors attained a diameter of 5 $\mathrm{mm}$, they were randomized into two groups. For control (group I), water was administered every day p.o. for 20 days and, $50 \mathrm{mg} / \mathrm{kg}$ P3155 (group II), P3155 solution in water was administered every day p.o. also for 20 days.

\section{Statistical analysis}

Statistical comparison was made using GraphPad PRISM $^{\circledR}$ (versions 3.0 and 5.0, GraphPad Software, Inc., USA) software where Student's unpaired $t$-test was employed. Statistical significance was evaluated by calculating $p$ values. Differences where $p<0.05$ were considered statistically significant. $\left({ }^{*} p<0.05 ; * * p<0.01\right.$, ${ }^{* * * *} p<$ $0.001)$. Densitometric analysis was carried out using ImageJ software.

\section{Results}

P3155 was identified by us as a potent HIF-1 $\alpha$ inhibitor in the reporter gene based assay [11]. Specificity index (SI) was calculated, obtained by dividing the $\mathrm{EC}_{50}$ in
U251-pGL3 by the $\mathrm{EC}_{50}$ in U251-HRE, which provides an indication of relative specificity towards inhibition of HIF-1 dependent transcription. P3155 had a SI of 7.1, indicating that it had minimal or no activity on the constitutive expression of luciferase in the U251-pGL3 control cell line (Figure 1, Table 1). As HIF-1 $\alpha$ protein is overexpressed in $\mathrm{PC}-3$ prostate cancer cell line, it was mainly used for all further studies [15].

\section{Effect of P3155 on HIF-1 $\alpha$ protein accumulation under hypoxia}

Studies were performed to ascertain the inhibition of hypoxia-induced overexpression of HIF-1 $\alpha$ protein in the treated cell samples using western blot analysis. P3155 showed complete abrogation of HIF-1 $\alpha$ in PC-3 cell line and was found to inhibit hypoxia-mediated HIF-1 $\alpha$ protein levels in PC-3 in a dose-dependent manner (Figure 2A).

\section{HIF-1 $\alpha$ inhibition by P3155 under hypoxia was proteasome independent}

HIF- $1 \alpha$ is degraded mainly through the proteasomal pathway. To determine whether P3155 treatment induced degradation of HIF-1 $\alpha$ via this pathway, we tested the effect of P3155 in presence of 26S proteasome inhibitor MG132 on levels of HIF-1 $\alpha$ expression. The level of expression of HIF-1 $\alpha$ in the presence of MG132/DFX was upregulated in PC-3 cells as compared with untreated control cells. Simultaneous addition of

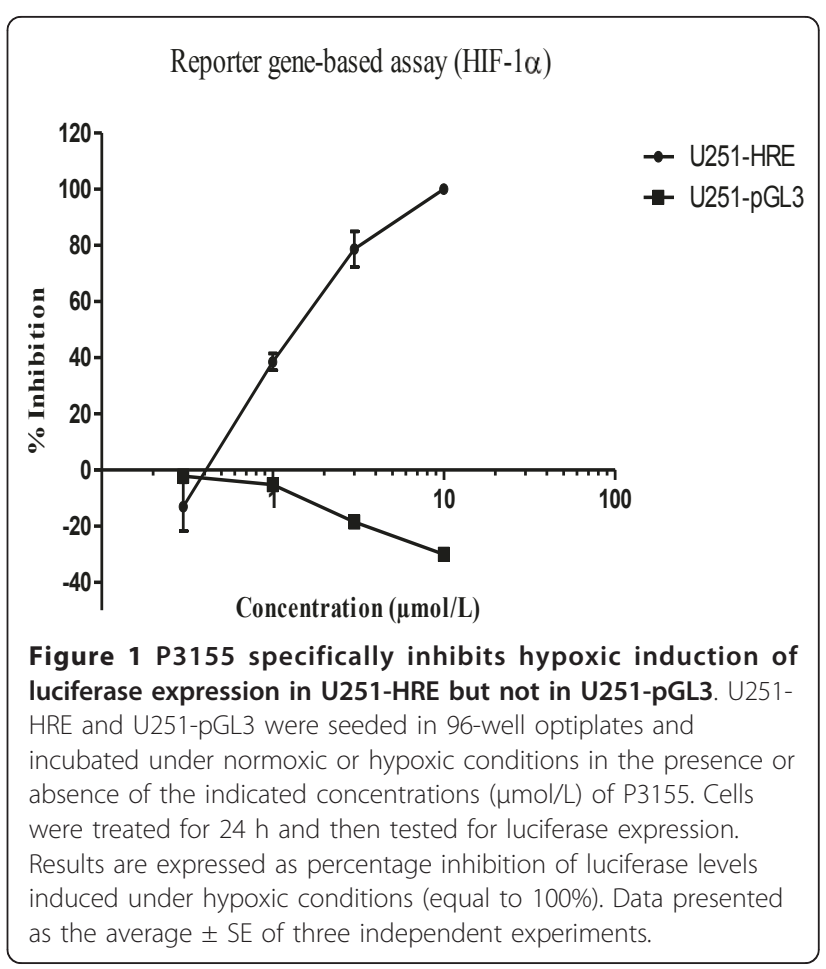


Table $1 \mathrm{EC}_{50}$ ( $\mu \mathrm{mol} / \mathrm{L}$ ) for P3155 and topotecan (standard) in the HIF-1 $\alpha$ reporter gene based assay

\begin{tabular}{llll}
\hline $\begin{array}{l}\text { Sr. } \\
\text { No. }\end{array}$ & $\begin{array}{l}\text { Compound } \\
\text { No }\end{array}$ & $\mathrm{EC}_{50}(\boldsymbol{\mu m o l} / \mathbf{L})$ & $\mathrm{EC}_{50}(\boldsymbol{\mu m o l} / \mathbf{L})$ \\
\hline & $\begin{array}{l}\text { U251-HRE (Hypoxia/ } \\
\text { DFX) }\end{array}$ & $\begin{array}{l}\text { U251-pGL3 } \\
\text { (normoxia) }\end{array}$ \\
\hline 01 & P3155 & 1.4 & $>10$ \\
\hline 02 & Topotecan & 0.06 & $>3.0$ \\
\hline
\end{tabular}

P3155 with MG132/DFX decreased accumulation of HIF-1 $\alpha$ (Figure 2B).

P3155 downregulates HIF-1 $\alpha$ mediated VEGF expression but does not inhibit HIF-1 $\alpha$ mRNA levels

Increased HIF- $1 \alpha$ expression promotes transcriptional activation of many genes VEGF being a prime candidate. Thus, we determined the levels of VEGF expression that were upregulated by hypoxia-mediated HIF-1 transcriptional activation. P3155 treatment significantly inhibited DFX-stimulated levels of VEGF mRNA. As P3155 was found to act on HIF-1 $\alpha$ expression via proteasome-independent pathway, the possibility of it inhibiting HIF- $1 \alpha$ transcription was considered. Thus, HIF- $1 \alpha$ mRNA levels after P3155 treatment of cells under hypoxia were checked using RT-PCR. P3155 seemed to have no effect on HIF-1 $\alpha$ mRNA levels (Figure 3A).

\section{Effect of P3155 on hypoxia-mediated accumulation of HIF-1 $\alpha$ and VEGF}

The ability of P3155 to inhibit HIF-1 $\alpha$ activity was tested by evaluating levels of transcriptionally active HIF-1 $\alpha$ protein expressed in the nuclei of prostate cancer cells PC-3 and DU145 exposed to hypoxia. Treatment of cells with DFX induced accumulation of active

\section{(A)}
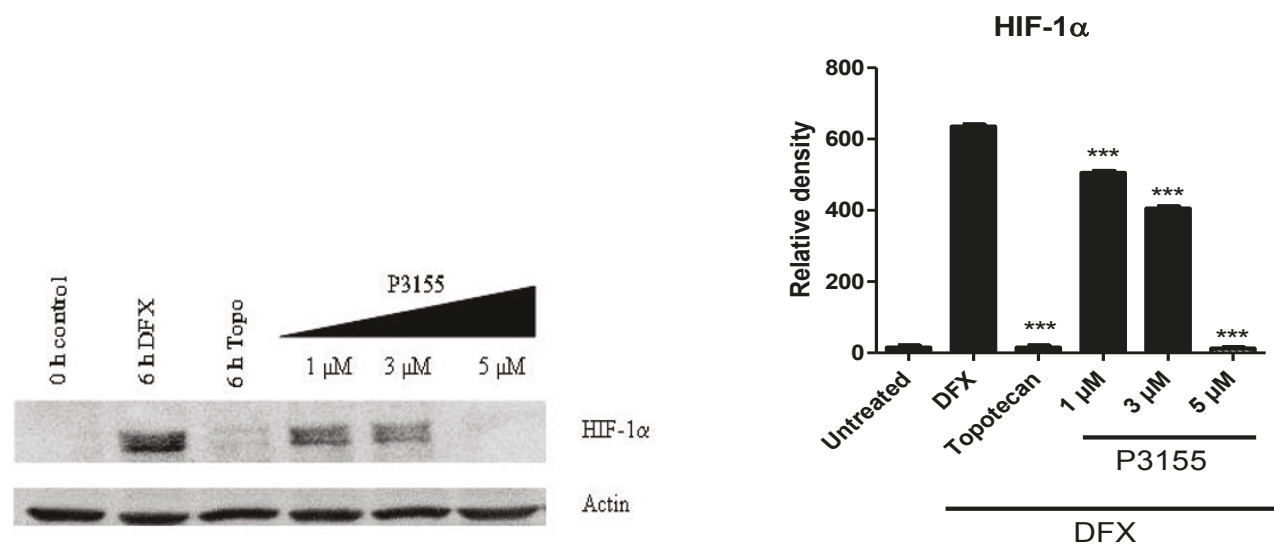

(B)
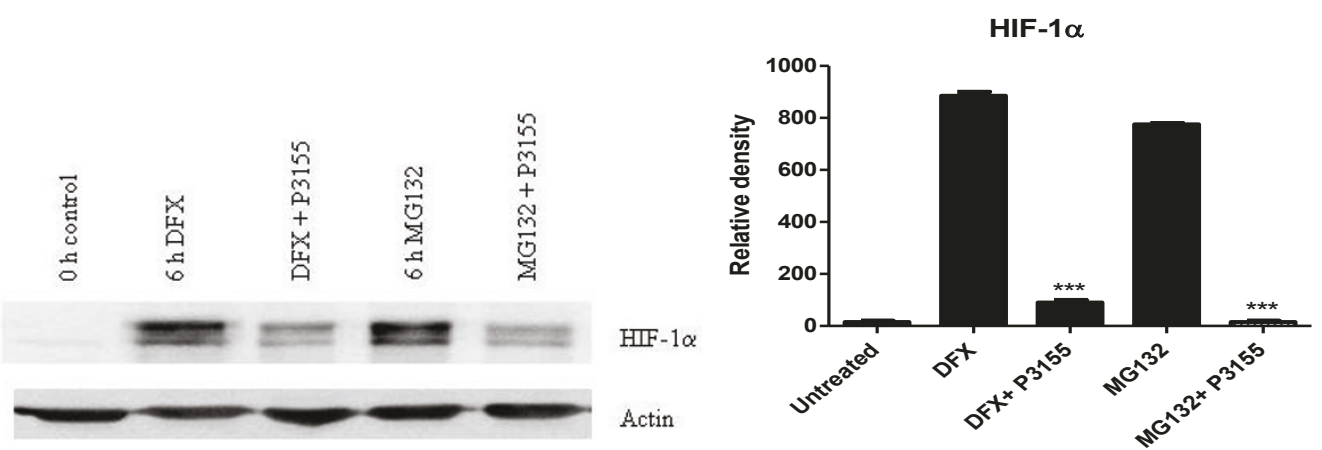

Figure 2 P3155 specifically inhibits HIF-1 $\alpha$ protein accumulation under hypoxia. PC-3 cells were treated with hypoxic mimic DFX (60 $\mu \mathrm{mol} / \mathrm{L}$ ) in the presence and absence of P3155 for $8 \mathrm{~h}$, and then protein extracts were prepared as described in 'Materials and Methods' (A) Downregulation of HIF-1 $\alpha$ protein by P3155 under hypoxia in a dose-dependent manner (B) P3155 inhibited hypoxia-mediated HIF-1 $\alpha$ accumulation in presence of DFX as well as MG132 (proteasome inhibitor) indicating that it inhibits HIF-1 $\alpha$ independent of the proteasome activity. 
(A)
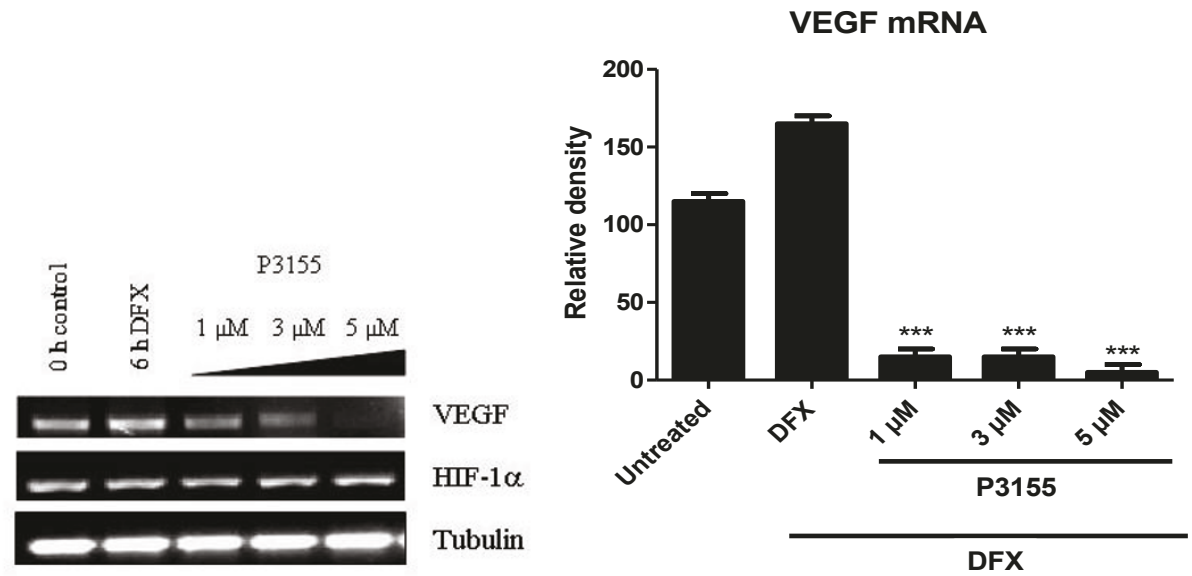

(B)

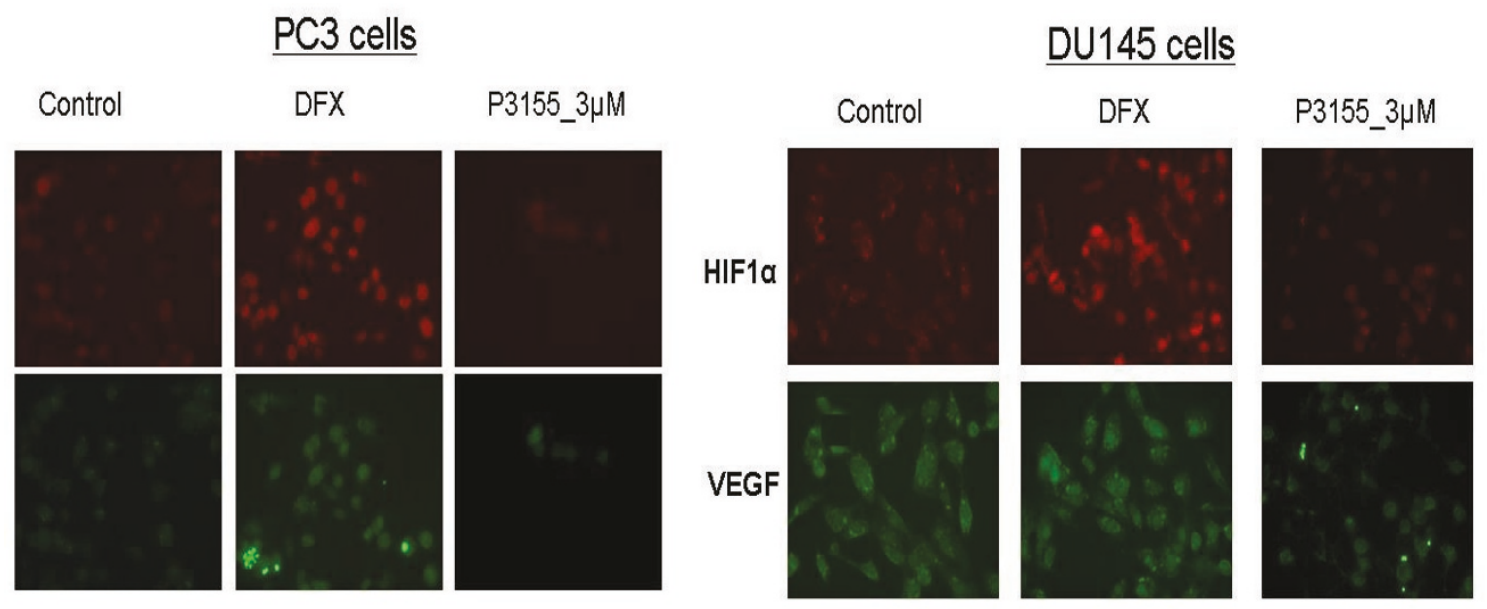

Figure 3 (A) P276 specifically inhibits VEGF mRNA expression under hypoxia in a dose-dependent manner in PC-3 cells. However, HIF$1 \alpha$ mRNA levels remained unchanged. (B) Inhibition of HIF-1 $\alpha$ and VEGF expression in PC-3 and DU145 prostate cancer cells by P3155. Cells were treated with P3155 $(3 \mu \mathrm{M})$ for $8 \mathrm{~h}$ at $37^{\circ} \mathrm{C}$ and stained with mouse antibody against HIF-1 $\alpha$ and rabbit antibody against VEGF. Reduced coexpression of HIF-1 $\alpha$ and VEGF was observed.

HIF-1 $\alpha$ protein (Figure 3B red signal) as well as its downstream target VEGF protein (green signal) within the nucleus. P3155 treatment induced a decrease in the co-accumulation of active HIF- $1 \alpha$ as well as VEGF protein under hypoxia.

\section{P3155 inhibits HIF-1 $\alpha$ and PI3K signaling pathway under hypoxia}

Translation of HIF-1 $\alpha$ mRNA has been previously suggested to be under the control of the phosphatidylinositol 3-kinase (PI3K) signaling pathway in various cell types [16-18]. To test whether P3155 inhibits this pathway thus probably leading to HIF- $1 \alpha$ translational downregulation, effect of P3155 on PI3K pathway was studied using PC-3 in which this pathway is constitutively active due to PTEN mutation $[19,20]$. PI3K inhibition by P3155 was seen in PC-3 cells as shown by decreased phosphorylation of the downstream targets, Akt and 4E-BP1 besides HIF-1 $\alpha$ under hypoxia (Figure 4).

\section{Effect of P3155 on cancer cell migration}

The hallmark of tumor cells is their ability to migrate and metastasize. Prostate cancers are known to metastasize in a high percentage of the cases, which is obviously linked 


\section{(A)}

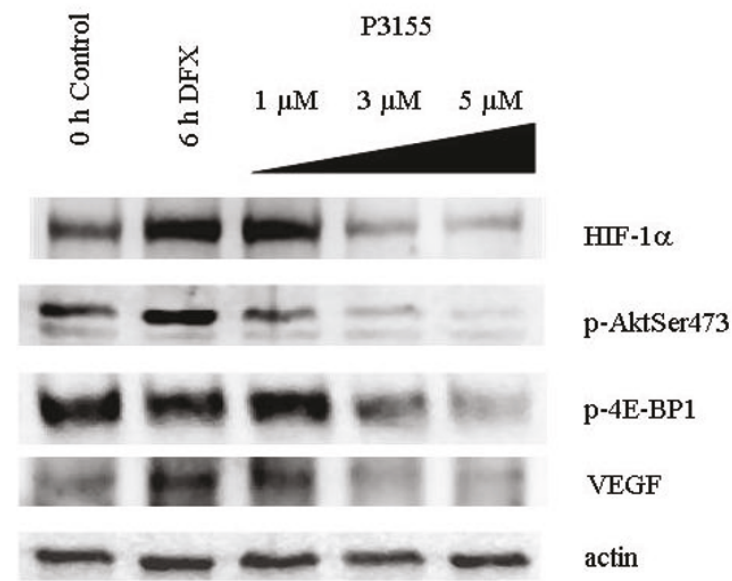

(B)
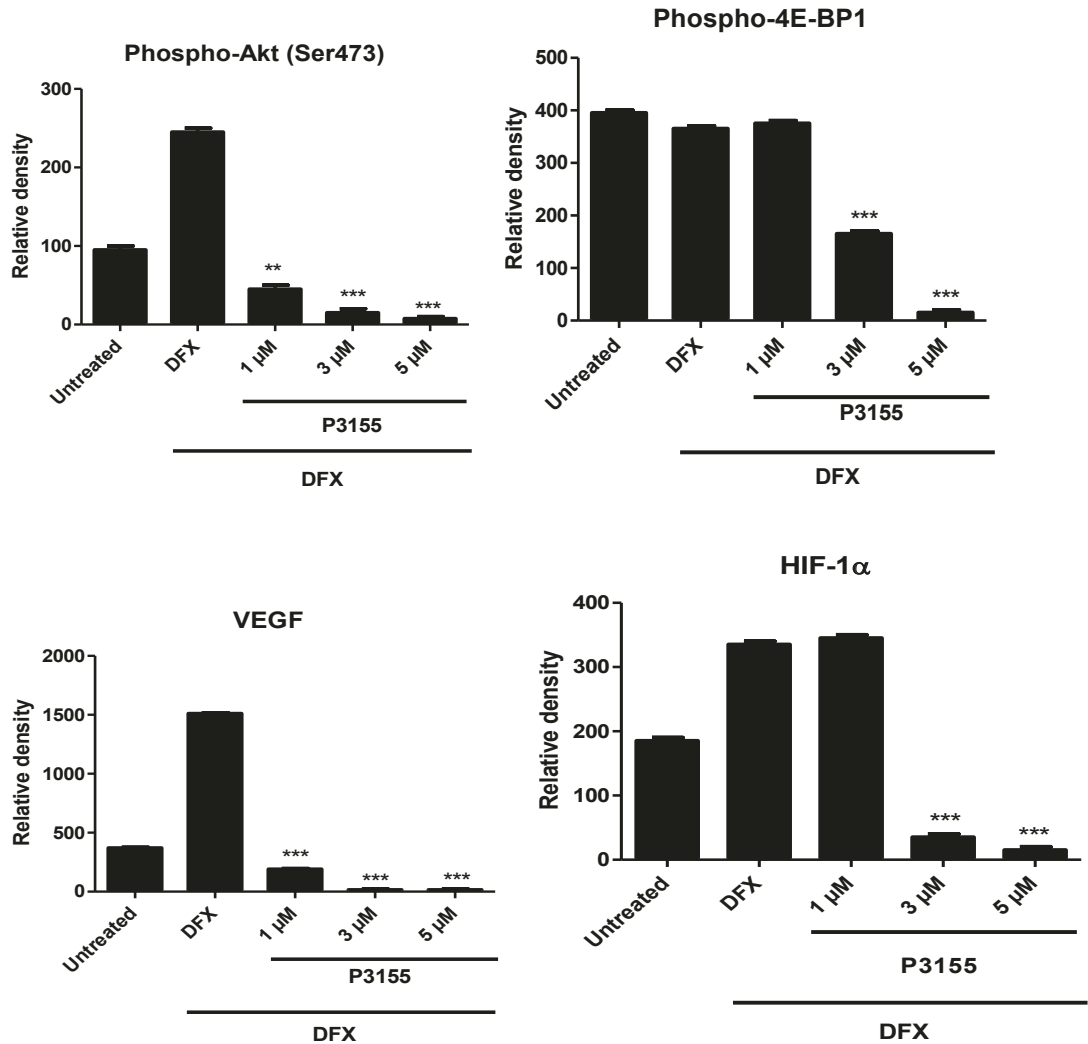

Figure 4 P3155 downregulates HIF-1 $\alpha$ expression as well as PI3K/Akt pathway under hypoxic conditions. (A) PC-3 cells were treated with given concentrations of P3155 under hypoxia and its effect on protein levels of HIF-1 $\alpha$, phospho-Akt, phospho-4E-BP1 and VEGF was determined using western blot analysis (B) densitometric analysis was carried out for each protein. 
to a poor prognosis. Therefore, potential effect of P3155 on cancer cell migration was tested using the prostate cancer cell lines, DU145 and PC-3. The results demonstrated that P3155 inhibited cell migration of DU145 and PC-3 cells more than two-fold in a dose-dependent manner in the presence of serum (Figure 5A).

\section{Effect of P276 on tube formation of HUVECs}

We next evaluated the effect of P3155 on the formation of functional tubes by HUVECs plated on the Matrigel, a reconstituted extracellular matrix preparation. Serum was used as the stimulator in this study [21]. In the control group stimulated with serum, HUVECs rapidly aligned with one another and formed tube-like structures resembling a capillary plexus within $24 \mathrm{~h}$, which required cell-matrix interaction, intercellular interaction and cell motility. P3155 prevented serum-stimulated tube formation of HUVECs in a dose-dependent manner and no cytotoxicity was observed at these particular concentrations (Figure 5B). At the same timepoint and concentrations, P3155 downregulated phospho-Akt (Ser 473) levels in a dose-dependent and significant manner (Figure 5B).

\section{Effect of P3155 on tumor growth in vivo}

Because of the observed in vitro effects of P3155, we investigated whether it inhibits tumor growth in vivo. To confirm the in vivo activity of $\mathrm{P} 3155$, antitumor efficacy of P3155 in xenograft model of PC-3 was studied. The average tumor weights on day 20 for control and P3155 were $933 \pm 285.6 \mathrm{mg}$ and $358.6 \pm 143.9 \mathrm{mg}$ respectively and the calculated highest percentage of growth inhibition was observed to be $61 \%$ on day 9 after randomization (Figure 6, $p<0.05$ ). Mice treated with P3155 had no significant weight loss while on the study drug (data not shown). These results indicate that P3155 effectively inhibits tumor growth in tumor bearing mice.

\section{Discussion}

Overexpression of HIF- $1 \alpha$ is a common feature of solid malignancies and is correlated with advanced disease stage, increased angiogenesis and poor prognosis [21]. HIF-1 induces expression of genes whose products are involved in cancer cells' survival, glycolysis, angiogenesis, migration and invasion [22]. As a result, HIF-1 has emerged as an attractive molecular target for the development of novel cancer therapeutics. P3155 was identified as a potent and specific inhibitor of HIF-1 transcriptional activation in the reporter gene-based assay. Genetic features of PC-3 prostate cancer cells such as loss of PTEN, constitutive activation of PI3K/ Akt pathway, overexpression of HIF-1 $\alpha$, p53 negativity make them an attractive model for studying the mode of action of HIF- $1 \alpha$ inhibitors and they have been employed by several groups for such studies earlier [23-25]. Hence, we selected PC-3 cells to elucidate the mechanism of action of P3155 under hypoxia. Since the HIF-1 pathway can be inhibited at several different points, including post-translational modification, gene transcription, or protein translation, next we investigated whether P3155 had any effect on proteasomal degradation of HIF- $1 \alpha$ protein, or synthesis of its mRNA or protein. We found that HIF-1 $\alpha$ protein downregulation by P3155 is independent of the ubiquitin-proteasomal pathway as blocking P3155-induced HIF-1 $\alpha$ protein degradation with the proteasome inhibitor MG132 failed to restore HIF-1 $\alpha$ protein expression (Figure 2B). Also our present results indicate that P3155 induced degradation of HIF-1 $\alpha$ protein in a dose-dependent manner with no effect on HIF- $1 \alpha$ mRNA levels (Figure 3A). Possibility of inhibition of HIF-1 $\alpha$ by P3155 at the translational level was therefore considered.

It was previously shown that HIF-1 $\alpha$ protein could be stimulated by serum and other growth factors via the phosphotidyl-3-kinase pathway [26]. The PI3K/Akt pathway is activated by hypoxia in certain cell types and interference with the Akt reduces accumulation of HIF in response to hypoxia [27]. This pathway also plays a key role in the control of HIF-1 $\alpha$ translation and synthesis in prostate cancer cells. Inhibition of coexpression of HIF-1 $\alpha$ and VEGF was observed by immunofluorescence in PC-3 and DU145 prostate cancer cells (Figure 3B). Treatment of hypoxic PC-3 cells with P3155 resulted in reduced HIF-1 $\alpha$ expression as well as decreased phosphorylation of Akt and its downstream effector 4E-BP1, which controls the initiation of protein translation under hypoxia [28] in a dose-dependent manner (Figure 4). These observations support the hypothesis that PI3K/Akt pathway could be involved in P3155-mediated HIF-1 $\alpha$ inhibition by inhibition of its translation.

Abrogation of HIF-1 $\alpha$ and VEGF expression by P3155 was demonstrated by immunofluorescence. In the past few years the field of siRNAs has emerged at a surprisingly high pace. In the present study, we found that P3155 was as effective as HIF-1 $\alpha$ siRNA in HIF- $1 \alpha$ suppression. Upon transfection with si-RNA, there was dose-dependent inhibition of HIF-1 $\alpha$ at the protein level (Additional file 1, Figure S1). It was evident that suboptimal doses of both si-RNA and P3155 resulted in complete abrogation of HIF-1 $\alpha$ thus exhibiting synergism.

Tumor invasion and metastasis are essential for tumor growth and are also directly regulated by HIF- $1 \alpha$. Wound healing assays are a classic and commonly used method for studying cell migration and the biology underlying it. The assay has been used for studying cell 


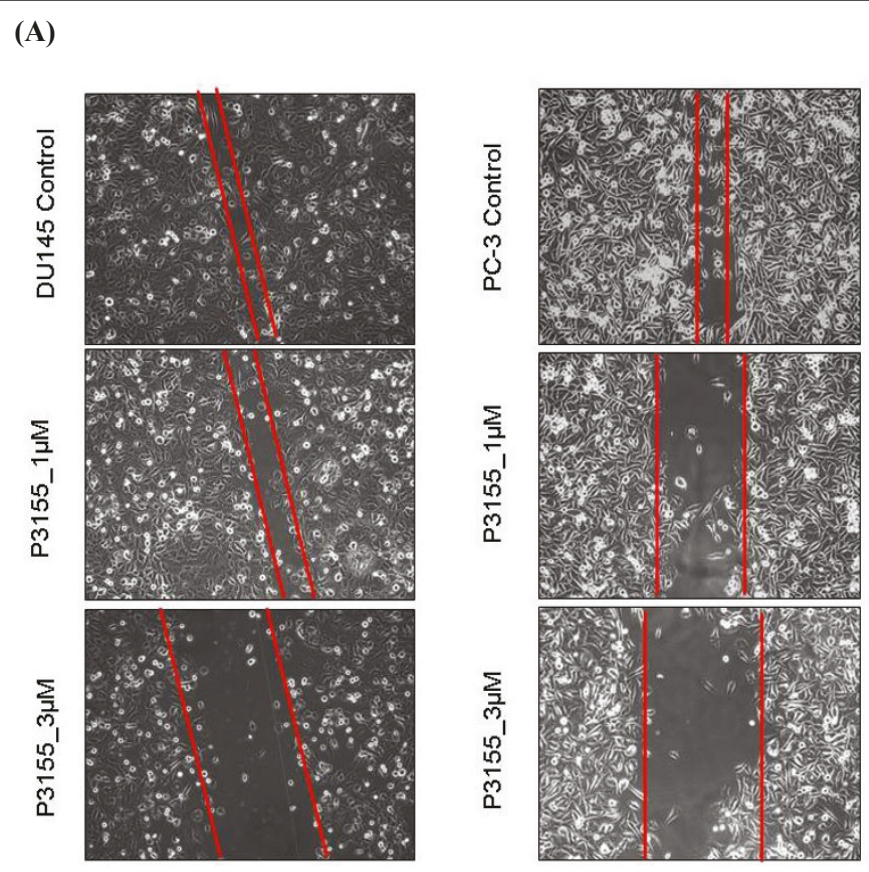

(B)
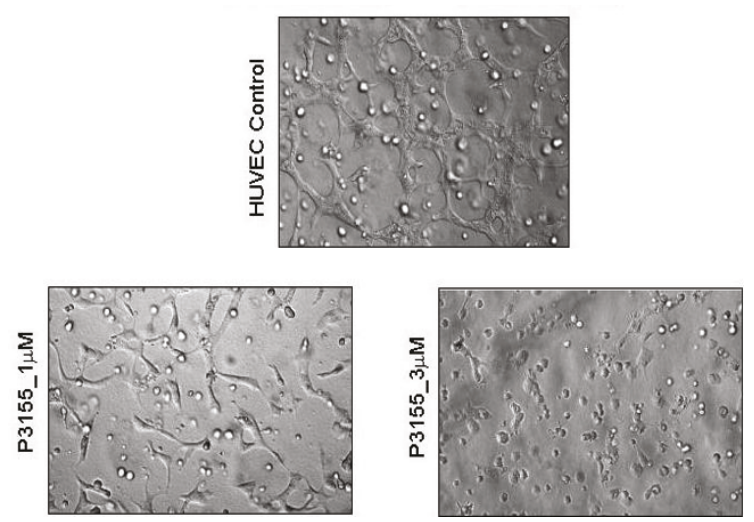

(C)
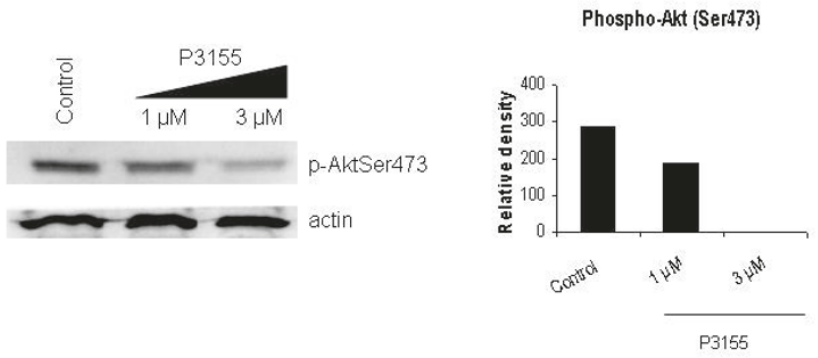

Figure 5 (A) Effect of P3155 on PC-3 and DU-145 cell migration (B) Effect of P3155 on HUVEC tube formation (C) P3155 downregulates PI3K/Akt pathway as evident by inhibition of phospho-Akt (Ser 473) levels in HUVECs at the same concentrations and timepoint. 


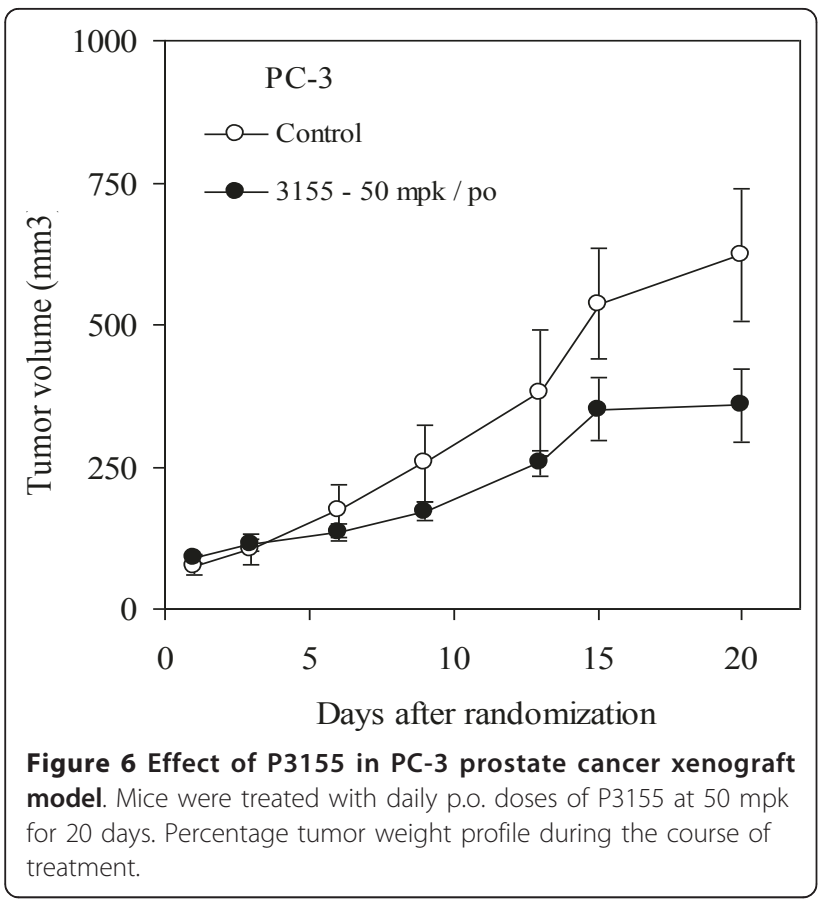

polarization, matrix remodeling, cell migration as well as a proxy for angiogenesis, metastasis [29]. This assay was employed to assess the anti-migratory potential of P3155. Prostate cancer cells were selected for this study because of their invasiveness in vitro. As shown in Figure 5a, P3155 potently inhibited wound healing of these cells and no toxicity was observed. One of the most widely used in vitro assays to model the reorganization stage of angiogenesis is the tube formation assay. The assay measures the ability of endothelial cells, plated at subconfluent densities with the appropriate extracellular matrix support, to form capillary-like structures [30,31]. P3155 effectively blocked tube formation by HUVEC cells as shown in Figure $5 \mathrm{~b}$ in a dose-dependent manner. It also inhibited PI3K/Akt pathway which was evident by decreased phospho-AktSer473 levels. Taken together, these results suggest that P3155 inhibits cell migration and angiogenesis via inhibition of HIF- $1 \alpha$ and PI3K/Akt pathway.

A number of anti-cancer agents have been reported to decrease HIF-1 $\alpha$ activity in cells in culture however, only a few of the reported HIF- $1 \alpha$ inhibitors demonstrated antitumor activity in vivo $[32,8]$. Because of promising in vitro results of our identified HIF-1 $\alpha$ inhibitor, we examined tumor growth inhibition due to P3155 treatment. The human xenograft model showed efficacy of P3155 in prostate cancer when given by p.o. route. It showed significant anti-tumor activity with $61 \%$ growth inhibition. These results suggest that P3155 is an inhibitor of HIF-1 that halts tumor growth by blocking tumor adaptation to hypoxia and thus can be used as a therapeutic modality for aggressive prostate cancer.

\section{Conclusion}

In summary, we conclude from these studies that P3155 is a specific inhibitor of HIF- $1 \alpha$ and it also abrogates PI3K pathway. We confirmed the inhibitory effects of P3155 on expression of HIF- $1 \alpha$ and on the induction of VEGF under hypoxia by western blot analysis and immunofluorescence. It showed significant antiangiogenic potential on prostate cancer cells and in vivo, treatment with P3155 halted the growth of xenograft tumor originating from PC-3 cells.

\section{Conflict of interests}

The authors declare that they have no competing interests.

\section{Additional material}

Additional file 1: Synergistic effect of HIF- $1 \alpha$ siRNA and P3155 on HIF- $1 \alpha$ expression. To compare the effect of HIF- $1 \alpha$ siRNA and P3155 on HIF-1 $\alpha$ protein expression, PC-3 cells were transfected with optimal concentrations of siRNA and P3155 i.e. $20 \mathrm{nM} \mathrm{HIF-1} \alpha$ specific siRNA or scrambled siRNA or P3155 (3 $\mu \mathrm{M})$ under hypoxia. The results showed that hypoxia-induced HIF-1 $\alpha$ protein expression was completely suppressed on transfection with HIF-1 $\alpha$ siRNA alone or P3155 treatment alone (Figure). Transfection with HIF-1 $\alpha$ siRNA combined with P3155, both used at suboptimal concentrations, also resulted in complete abrogation of active HIF-1 $\alpha$ expression as shown in Figure. Thus, both these agents when used together showed a synergistic effect.

\section{Acknowledgements}

The work has been supported and carried out at Piramal Life Sciences Limited, Goregaon, Mumbai, India. We extend our thanks for the support.

\section{Author details}

${ }^{1}$ Department of Pharmacology, Piramal Life Sciences Limited, 1-Nirlon Complex, Goregaon, Mumbai-400 063, India. ²Department of Medicinal Chemistry, Piramal Life Sciences Limited, 1-Nirlon Complex, Goregaon, Mumbai-400 063, India. ${ }^{3}$ Target Identification Group, Piramal Life Sciences Limited, 1-Nirlon Complex, Goregaon, Mumbai-400 063, India.

\section{Authors' contributions}

SMM carried out the cell culture, treatment and mechanistic studies, analyzed the data and wrote the manuscript. AP and AJ designed and performed the migration, tube formation and immunofluorescence experiments. VS performed the in vivo experiment. MJR read and edited the manuscript. SK synthesized the molecule. KSJ contributed to the design of the experiment, read and gave final approval of the version to be submitted.

All the authors have read and approved the final manuscript.

Received: 14 March 2011 Accepted: 5 August 2011

Published: 5 August 2011

\section{References}

1. Hockel M, Vaupel P: Tumor hypoxia: definitions and current clinical, biologic, and molecular aspects. Journal of the National Cancer Institute 2001, 93:266-276. 
2. Harris AL: Hypoxia-a key regulatory factor in tumour growth. Nature Reviews Cancer 2002, 2:38-47.

3. Blancher C, Harris AL: The molecular basis of the hypoxia response pathway: tumour hypoxia as a therapy target. Cancer Metastasis Reviews 1998, 17:187-194.

4. Wouters BG, Van den Beucken T, Magagnin MG, Lambin P, Koumenis C: Targeting hypoxia tolerance in cancer. Drug Resistance Updates 2004, 7:25-40.

5. Ivan M, Kondo K, Yang H, Kim W, Valiando J, Ohh M, Salic A, Asara JM, Lane WS, Kaelin WG Jr: HIFalpha targeted for VHL-mediated destruction by proline hydroxylation: implications for $\mathrm{O} 2$ sensing. Science (Wash. DC) 2001, 292:464-468

6. Jaakkola P, Mole DR, Tian YM, Wilson MI, Gielbert J, Gaskell SJ, Kriegsheim AV, Hebestreit HF, Mukherji M, Schofield CJ, Maxwell PH, Pugh CW, Ratcliffe PJ: Targeting of HIF-alpha to the von Hippel-Lindau ubiquitylation complex by $\mathrm{O}_{2}$-regulated prolyl hydroxylation. Science 2001, 292:468-472.

7. Zhong H, De Marzo AM, Laughner E, Lim M, Hilton DA, Zagzag D, Buechler P, Isaacs WB, Semenza GL, Simons JW: Overexpression of hypoxia-inducible factor 1alpha in common human cancers and their metastases. Cancer Research 1999, 59:5830-5835.

8. Patiar S, Harris AL: Role of hypoxia-inducible factor-1a as a cancer therapy target. Endocrine Related Cancer 2006, 13:61-75.

9. Maxwell PH, Dachs GU, Gleadle JM, Nicholls LG, Harris AL, Stratford IJ, Hankinson O, Pugh CW, Ratcliffe PJ: Hypoxia-inducible factor-1 modulates gene expression in solid tumors and influences both angiogenesis and tumor growth. Proceedings of the National Academy of Sciences USA 1997, 94:8104-8109.

10. Sun X, Kanwar JR, Leung E, Lehnert K, Wang D, Krissansen GW: Gene transfer of antisense hypoxia-inducible factor-1a enhances the therapeutic efficacy of cancer immunotherapy. Gene Therapy 2001, 8:638-645.

11. Yewalkar N, Deore V, Padgaonkar A, Manohar S, Sahu B, Kumar P, JalotaBadhwar A, Joshi KS, Sharma S, Kumar S: Development of novel inhibitors targeting HIF-1 towards anticancer drug discovery. Bioorganic Medicinal Chemistry Letters 2010, 20:6426-6429.

12. Rapisarda A, Uranchimeg B, Scudiero DA, Selby M, Sausville EA, Shoemaker RH, Melillo G: Identification of small molecule inhibitors of hypoxia-inducible factor-1 transcriptional activation pathway. Cancer Research 2002, 62:4316-4324.

13. Alvarez-Tejado M, Naranjo-Suarez S, Jimenez C, Carrera AC, Landazuri MO, del Paso L: Hypoxia Induces the Activation of the Phosphatidylinositol 3Kinase/Akt Cell Survival Pathway in PC12 Cells. Journal of Biological Chemistry 2001, 276(25):22368-22374.

14. Koh MY, Spivak-Kroizman T, Venturini S, Welsh S, Williams RR, Kirkpatrick DL, Powis G: Molecular mechanisms for the activity of PX-478, an antitumor inhibitor of hypoxia-inducible factor-1a. Molecular Cancer Therapeutics 2008, 7(1):90-100.

15. Saramaki OR, Savinanainen KJ, Nupponen NN, Bratt O, Visakorpi T: Amplification of hypoxia-inducible factor 1alpha gene in prostate cancer. Cancer Genetics and Cytogenetics 2001, 128:31-34.

16. Treins C, Giorgetti-Peraldi S, Murdaca J, Semenza GL, Van Obberghen E: Insulin stimulates hypoxia-inducible factor 1 through a phosphatidylinositol 3-kinase/target of rapamycin-dependent signaling pathway. Journal of Biological Chemistry 2002, 277:27975-27981.

17. Stiehl DP, Jelkmann $W$, Wenger RH, Hellwig-Burgel T: Normoxic induction of the hypoxia-inducible factor 1 [alpha] by insulin and interleukin-1 [beta] involves the phosphatidylinositol 3-kinase pathway. FEBS Letters 2002, 512:157-162.

18. Laughner E, Taghavi P, Chiles K, Mahon PC, Semenza GL: HER2 (neu) Signaling increases the rate of Hypoxia-Inducible Factor $1\{a \mid p h a\}$ (HIF-1 \{alpha\}) synthesis: novel mechanism for HIF-1-mediated vascular endothelial growth factor expression. Molecular Cell Biology 2001, 21:3995-4000.

19. Fang J, Ding M, Yang L, Liu L-Z, Jiang B-H: PI3K/PTEN/AKT signaling regulates prostate tumor angiogenesis. Cellular Signaling 2007, 19:2487-2497.

20. Pore N, Gupta AK, Cerniglia GJ, Maity A: HIV protease inhibitors decrease VEGF/HIF-1a expression and angiogenesis in glioblastoma cells. Neoplasia 2006, 8(11):889-895.
21. Newcomb EW, Lukyanov Y, Schnee T, Ali MA, Lan L, Zagzag D: Noscapine inhibits hypoxia-mediated HIF-1alpha expression and angiogenesis in vitro: a novel function for an old drug. International Journal of Oncology 2006, 28:1121-1130.

22. Kong D, Park EJ, Stephen AG, Calvani M, Cardellina JH, Monks A, Fisher RJ, Shoemaker RH, Melillo G: Echinomycin, a small-molecule inhibitor of hypoxia-inducible factor-1 DNA binding activity. Cancer Research 2005 65(19):9047-9055.

23. Dikmen ZG, Gellert GC, Dogan P, Yoon H, Lee YB, Ahn CH, Shay JW: In vivo and in vitro effects of a HIF-1a inhibitor, RX-0047. Journal of Cellular Biochemistry 2008, 104:985-994.

24. Palayoor ST, Tofilon PJ, Coleman C-N: Ibuprofen-mediated reduction of hypoxia-inducible factors HIF-1a and HIF-2a in prostate cancer cells. Clinical Cancer Research 2003, 9:3150-3157.

25. Jiang B-H, Liu L-Z, Schafer R, Flynn DC, Barnett JB: A novel role for 3, 4dichloropropionanilide (DCPA) in the inhibition of prostate cancer cell migration, proliferation, and hypoxia-inducible factor 1 alpha expression. BMC Cancer 2006, 6:204.

26. Mabjeesh NJ, Post DE, Willard MT, Kaur B, Van Meir EG, Simons JW, Zhong $\mathrm{H}$ : Geldanamycin induces degradation of hypoxia-inducible factor 1-a protein via the proteasome pathway in prostate cancer cells. Cancer Research 2002, 62:2478-2482.

27. Sun H-L, Liu Y-N, Huang Y-T, Pan S-L, Huang D-Y, Guh J-H, Lee F-Y, Kuo S-C, Teng C-M: YC-1 inhibits HIF-1 expression in prostate cancer cells: contribution of Akt/NF-KB signaling to HIF-1a accumulation during hypoxia. Oncogene 2007, 26:3941-3951.

28. Van den Beucken T, Koritzinsky M, Wouters BG: Translational control of gene expression during hypoxia. Cancer Biology and Therapy 2006, 5:749-755.

29. Yarrow JC, Perlman ZE, Westwood NJ, Mitchison TJ: A high-throughput cell migration assay using scratch wound healing, a comparison of imagebased readout methods. BMC Biotechnology 2004, 4:21.

30. Davis GD, Senger D: Endothelial extracellular matrix: biosynthesis, remodeling, and functions during vascular morphogenesis and neovessel stabilization. Circulation Research 2005, 97(11):1093-1107.

31. Donovan D, Brown NJ, Bishop ET, Lewis CE: Comparison of three in vitro human 'angiogenesis' assays with capillaries formed in vivo. Angiogenesis 2001, 4(2):113-121.

32. Powis $G$, Kirkpatrick $L$ : Hypoxia inducible factor-1\{alpha\} as a cancer drug target. Molecular Cancer Therapeutics 2004, 3(5):647-654.

\section{Pre-publication history}

The pre-publication history for this paper can be accessed here: http://www.biomedcentral.com/1471-2407/11/338/prepub

\section{doi:10.1186/1471-2407-11-338}

Cite this article as: Manohar et al: A novel inhibitor of hypoxiainducible factor- $1 \alpha$ P3155 also modulates PI3K pathway and inhibits growth of prostate cancer cells. BMC Cancer 2011 11:338.

\section{Submit your next manuscript to BioMed Central and take full advantage of:}

- Convenient online submission

- Thorough peer review

- No space constraints or color figure charges

- Immediate publication on acceptance

- Inclusion in PubMed, CAS, Scopus and Google Scholar

- Research which is freely available for redistribution

Submit your manuscript at www.biomedcentral.com/submit
C Biomed Central 